\begin{tabular}{|c|l|}
\hline Title & Freezing Injury in Egg Cells of the Sea Urchin \\
\hline Author(s) & A SA HINA, Eizo \\
\hline Citation & Cellular Injury and Resistance in Freezing Organisms : proceedings, 2, 211-229 \\
\hline Issue Date & 1967 \\
\hline Doc URL & http:/hdl.handle.net/2115/20418 \\
\hline Type & bulletin (article) \\
\hline Note & $\begin{array}{l}\text { International Conference on Low Temperature Science. I. Conference on Physics of Snow and Ice, II. Conference on } \\
\text { Cryobiology. (A ugust, 14 19, 1966, Sapporo, Japan) }\end{array}$ \\
\hline File Information & \begin{tabular}{l} 
1_p211-229.pdf \\
\hline
\end{tabular} \\
\hline
\end{tabular}

Instructions for use 


\title{
Freezing Injury in Egg Cells of the Sea Urchin*
}

\author{
Éizo Asahina \\ 朝 比 奈 英三 \\ The Institute of Low Temperature Science \\ Hokkaido University, Sapporo, Japan
}

\begin{abstract}
By the use of appropriate experimental methods processes of various kinds of cellular injury during freezing and thawing were demonstrated in the egg cell of the sea urchin.

Intracellular freezing invariably results in fatal damage to the cells at least at temperatures above $-30^{\circ} \mathrm{C}$. At very high subfreezing temperatures the cause of injury in intracellularly freezing cells may be the result of a mechanical stress due to the rapid formation of ice crystals of large grain within the protoplasmic structure. At temperatures below $-8^{\circ} \mathrm{C}$, the processes of intracellular freezing in a cell is, as a rule, the so-called flashing. In the cells frozen in this manner a very rapid and strong dehydration from every part of the protoplasmic system as well as mechanical stress may be the main factor of injury.

In extracellularly freezing cells, injury usually increases as the temperature is lowered and the period of time is lengthened. The following injuries can be observed.

1. Injury caused by low temperature itself, assumably brought about by some hindrances in the metabolic process.

2. Injury caused by severe dehydration and assumably by high concentration of salts in the medium.

3. Injury in surface protoplasmic structure at the time of the formation of an eutectic mixture in the medium.

In addition to the injuries mentioned above, remarkable injury resulting from a rapid thawing was also observed in extracellularly frozen cells.

The nature of injuries and the mechanism of resistance in these cases are also discussed.
\end{abstract}

\section{Introduction}

A number of theories have been set forth concerning the mechanism of freezing injury in living cells. It is also well known that there are clear discrepancies between the hypotheses of freezing injury offered by botanists and those offered by zoologists or medical biologists. There is, however, no reason to believe that the cause of freezing injury is quite the same in most of the living cells. The main cause of freezing injury in a variety of organisms may probably be different depending on the characters of the cells. Besides, even in the same cell, freezing injury may possibly occur in various different ways.

Fortunately the egg cell of the sea urchin is one of the best materials to observe the processes of various kinds of injury during freezing and thawing. The purpose of the present paper is to demonstrate the occurrence of several types of freezing injury in sea urchin egg cells in the hope that some discrepancies between the contradictory

* Contribution No. 783 from the Institute of Low Temperature Science. 
theories on the mechanisms of freezing injury which have been presented so far by some cryobiologists may be elucidated.

In the following observation unfertilized egg cells of the sea urchin, Strongyrocentrotus nudus were generally used as material, unless otherwise specifically stated.

\section{Supercooling}

In most cases, supercooling of living organisms brings about no harmful effect unless the period of cooling is prolonged. Even for a period as long as one hundred days or more some overwintering invertebrate animals can survive supercooling. A certain type of protoplasm of animal or plant especially in a very active stage of growth, however, is highly susceptible to low temperature itself. The egg cells of the sea urchin are
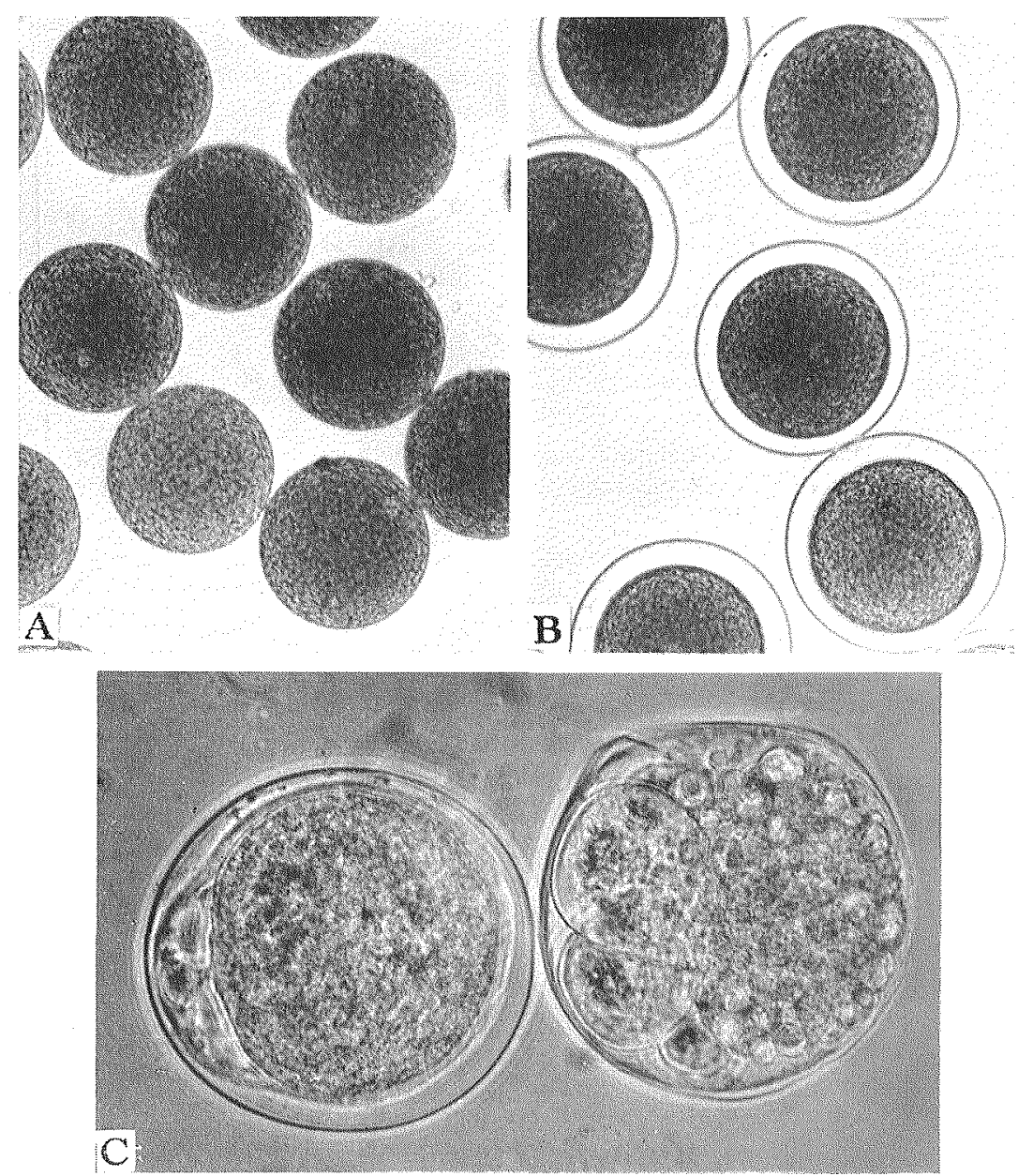

Fig. 1. Supercooling in egg cells of Strongyrocentrotus intermedius

A : Normal unfertilized egg cells. $\times 190$

B : Normal fertilized egg cells. $\times 190$

C : Fertilized egg cells supercooled at $-10^{\circ} \mathrm{C}$ for 2 days. $\times 400$ 
also one of the good examples of such susceptible forms, although they are relatively resistant to cooling at nearzero temperatures.

A small amount of egg cell suspension in sea water covered with paraffin oil were placed in a test tube or in a hollow slide glass. The egg cell suspension prepared in this manner can be safely kept at $-10^{\circ} \mathrm{C}$ for a few days without spontaneous freezing. The supercooled egg cells survived normally for a few hours at $-10^{\circ} \mathrm{C}$ and after rewarming they commenced to develope following insemination. After one day at $-10^{\circ} \mathrm{C}$, however, all of them were irreversibly injured without any remarkable change in appearance. Almost all of them remained intact but failed to develop with remarkable bubble formation after insemination (Fig. 1). The formation of bubbles or blisters observed in supercooled sea urchin egg cells is entirely similar in every respect to that observed in the plasmodium of a slime mold, Physarum polycepharum, at nearzero temperatures as reported by Gehenio and Luyet (1939). Bubble formation or blistering may perhaps be a common process of cold injury in various living cells susceptible to cooling. It is of interest to note that only exposure of egg cells to a low temperature for a short time is as dangerous as extracellular freezing at least at $-10^{\circ} \mathrm{C}$ (Table 1 ).

Table 1. Percentage survival after supercooling or extracellular freezing at $-10^{\circ} \mathrm{C}$ for a few days in the egg cells of Strongyrocentrotus intermedius

\begin{tabular}{|c|c|c|c|c|c|}
\hline & & \multicolumn{2}{|c|}{ Supercooling } & \multicolumn{2}{|c|}{ Extracellular freezing } \\
\hline & & $\begin{array}{l}\text { Apparently } \\
\text { intact cells }\end{array}$ & $\begin{array}{l}\text { Developed } \\
\text { cells* }\end{array}$ & $\begin{array}{l}\text { Apparently } \\
\text { intact cells }\end{array}$ & $\begin{array}{l}\text { Developed } \\
\text { cells* }\end{array}$ \\
\hline \multirow{5}{*}{ Unfertilized cell } & $0 \mathrm{hr}$ & 100 & 98 & 100 & 98 \\
\hline & $2 \mathrm{hrs}$ & 100 & 97 & 100 & 98 \\
\hline & $6 \mathrm{hrs}$ & 92 & 33 & 21 & 10 \\
\hline & 1 day & 93 & 0 & 1 & 0 \\
\hline & 2 days & 40 & 0 & 0 & 0 \\
\hline \multirow{2}{*}{ Fertilized cell } & 1 day & 35 & 10 & 77 & 0 \\
\hline & 2 days & 10 & 0 & 13 & 0 \\
\hline
\end{tabular}

* Percentage of the cells capable of cell division in total number of cooled cells with the same treatment

\section{Intracellular Freezing}

Process of injury. Intracellular freezing has proved fatal in various living cells except in the case of extremely rapid cooling (Asahina, 1965). In sea urchin egg cells an appreciable formation of intracellular ice, so far as observed under a microscope, was invariably lethal. Very rapidly frozen egg cells were sometimes observed to be as transparent as intact cells, but they soon became intensely dark at temperatures above $-30^{\circ} \mathrm{C}$ as a result of the formation of very fine ice crystals throughout the cell.

The most common type of intracellular freezing in sea urchin egg cells is the socalled flashing (Luyet and Gibbs, 1937; Asahina, 1953) or "black out". Flashing usually takes place independently in each cell when the egg cells are cooled somewhat rapidly with extracellular ice at temperatures between -8 and $-30^{\circ} \mathrm{C}$. On flashing the cell 
becomes instantaneously opaque and dark shortly after it was covered with extracellular ice (Fig. 2). The instant darkening of the freezing cell is reasonably explained to be the result of very rapid formation of numerous fine ice crystals, which are so minute that all the transmitted light is scattered, throughout the entire cell. Cells so frozen never contracted and the fine intracellular ice crystals were readily fused into larger ice masses at least at temperatures above $-25^{\circ} \mathrm{C}$. In the process of flashing, intracellular ice sometimes appeared to grow as very fine dendritic crystals and then they were divided into numerous small ice particles which became larger in size and smaller in number depending on the temperature they were exposed to. After thawing from
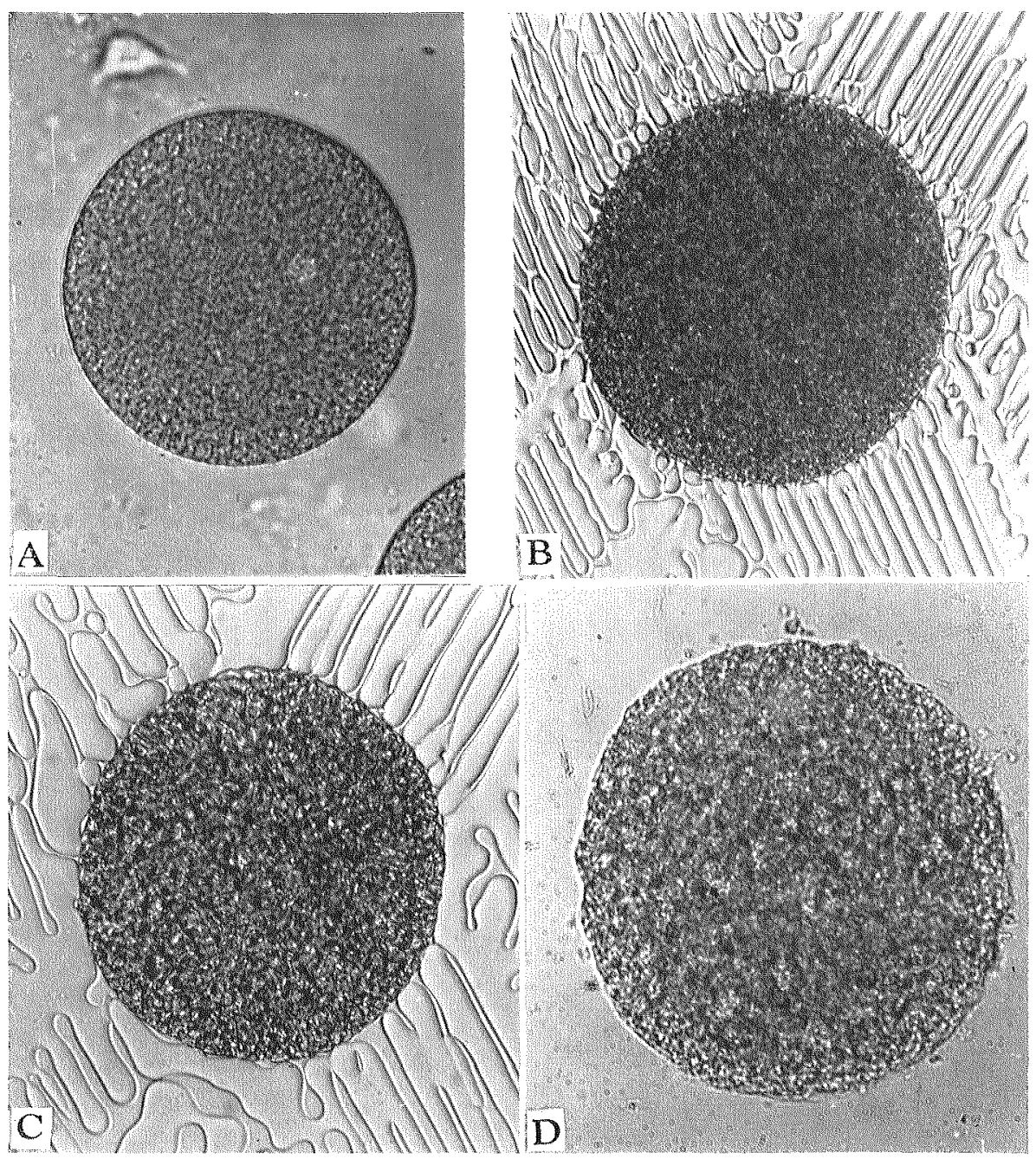

Fig. 2. Intracellular freezing in an egg cell of St. nudus at $-10^{\circ} \mathrm{C}, \quad \times 380$

A : Normal unfertilized egg cell

B : Frozen cell, immediately after flashing at $-10^{\circ} \mathrm{C}$

$\mathrm{C}$ : Same as $\mathrm{B}, 1$ minute later at $-10^{\circ} \mathrm{C}$

D: Thawed cell, showing coagulated protoplasm (B. C. from Asahina, 1965) 
flashing for a few minutes at temperatures around $-10^{\circ} \mathrm{C}$, egg cells appeared dark and granular, showing a characteristic pattern of coagulated protoplasm (Fig. 2D).

In normal sea water a spontaneous ice seeding into an egg cell by extracellular ice crystals is very difficult if the egg cell suspension is kept at a constant temperature
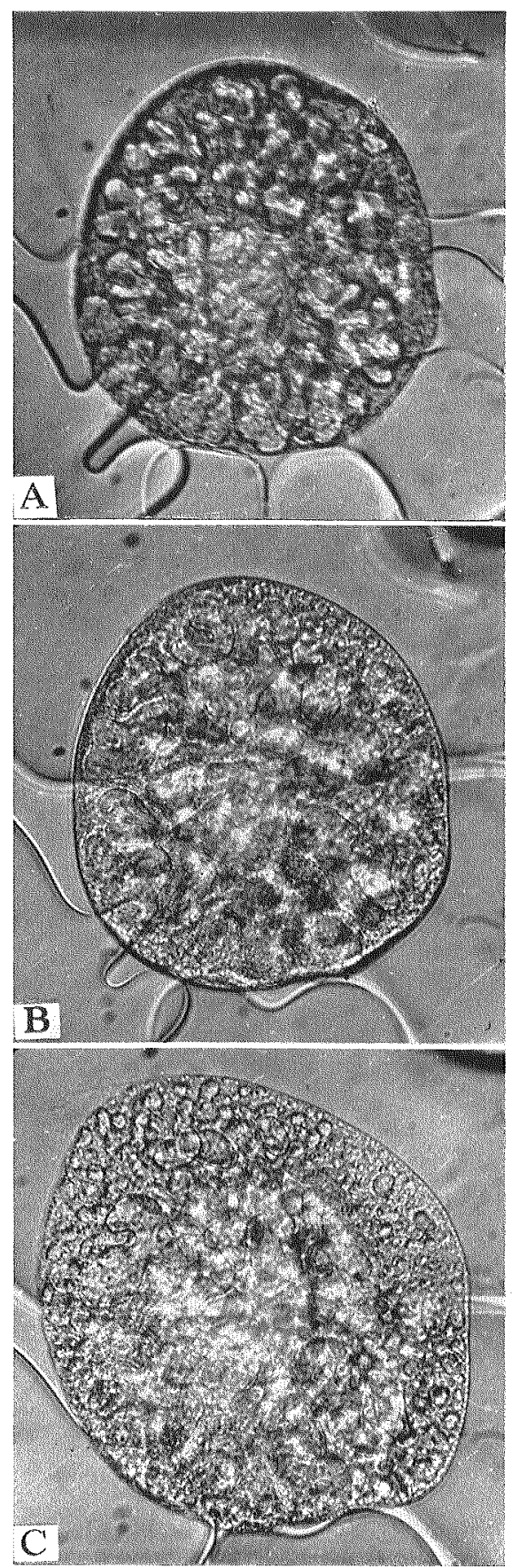
above $-6^{\circ} \mathrm{C}$. At high subzero temperatures intracellular ice formation can only be achieved by artificial inoculation into the cell with an icetipped pipet, and the process of intracellular freezing is clearly different from flashing. Ice slowly spread from the inoculated point to the entire cell as dendritic crystals for a very short time, but soon slender dendrite became broad to form irregular rosette-type crystals (Luyet and Rapatz, 1958). The highest temperature at which artificial ice seeding into the egg cell is successful was found to be about $-3.5^{\circ} \mathrm{C}$, although the egg cell can be easily dehydrated by an extracellular ice formation at any temperatures below the freezing point of sea water, that is about $-2^{\circ} \mathrm{C}$. At temperatures around $-4^{\circ} \mathrm{C}$, the process of intracellular freezing or rosette formation was completed within about 1 to 4 seconds. During such a slow intracellular freezing, formation of numerous small vacuoles immediately ahead of the growing ice branches was frequently observed in the protoplasm (Fig. 3). The process of the vacuole formation in freezing cells is quite similar in every respect to that in the precipitation reaction as a result of a drastic mechanical stress given at a small site of the cell (Heilbrunn, 1928). Egg cells frozen intracellularly at temperatures above $-6^{\circ} \mathrm{C}$ are very unstable. The ice crystals once formed inside the cell, even when the frozen cells were kept at a constant low temperature, were very apt to disappear and a complete cytolysis with

Fig. 3. Intracellular freezing at $-4^{\circ} \mathrm{C}$ in an egg cell of St. nudus. $\times 380$

A : Intracellular formation of "rosette" ice crystals (from Asahina, 1965)

B: Same as A, 1 minute later at $-4.2^{\circ} \mathrm{C}$

C: Same as B, 4 minutes later at $-4^{\circ} \mathrm{C}$, showing a remarkable vacuole formation throughout the cell 
swollen cytoplasm followed within several minutes (Fig. 3).

Formation of rosette-type ice crystals were sometimes observed inside the egg cells after partial dehydration by extracellular freezing at $-10^{\circ} \mathrm{C}$, perhaps by a spontaneous ice seeding from outside ice. In such a case, the ice slowly grew from one or a few points as irregular rosette crystals, and usually did not fill the entire cell. Upon thawing, however, these cells became remarkably dark following the disappearance of intracellular ice crystals, showing the characteristic granulous protoplasmic pattern of dark cytolysis (Heilbrunn, 1928). When these frozen cells were kept at a temperature of about $-10^{\circ} \mathrm{C}$, intracellular ice crystals decreased in size and the darkening of the protoplasm slowly proceeded.

Cause of injury. Judging from the process of cytolysis following vacuolization immediately ahead of the growing ice heads inside the cell, the main cause of injury in egg cells intracellularly frozen at very high subfreezing temperatures may assumably be a mechanical stress. This may be also the case of intracellularly frozen cells after partial dehydration by extracellular freezing at $-10^{\circ} \mathrm{C}$. In spite of the fact that extracellular freezing egg cells of St. nudus is entirely harmless at $-10^{\circ} \mathrm{C}$ at least for one hour (Table 3), intracellularly frozen cells were invariably killed regardless of the amount of ice formed within the cell or of the length of freezing period. In the case of the intracellularly frozen cells in which a small amount of ice formed, darkening of protoplasm at the time of rewarming were sometimes observed to spread from the site where intracellular ice crystal was formed. It is well known that the precipitation reaction inside a living cell is very apt to spread throughout the entire cell, even when the original injury occurred only at a small limited site in the cell (Heilbrunn, 1928).

Since flashing is a very rapid formation of numerous fine ice crystals of invisible size in every locus among the fine architecture of protoplasm, mechanical stress accompanied by a very rapid and strong dehydration from fully hydrated protoplasmic systems may reasonably be a main factor of injury. A possible cause of denaturation of protoplasm may be a drastic alternation of the interaction between water and protoplasmic protein, although the nature of change in water structure around protoplasmic protein by freezing is still uncertain.

Factors to prevent intracellular freezing. It was suggested in a previous paper (Asahina, 1961) that the main cause of freezing injury in a rapidly cooled egg cells was intracellular freezing, and that the initiation of such an intracellular freezing could be explained as a result of inoculation from the outside with ice crystals at least at a moderately low temperature. In fact, without any presence of outside ice crystals being in contact with cell surface, the egg cells can be safely kept unfrozen at $-10^{\circ} \mathrm{C}$ for a few days (Table 1), and even at temperatures between -15 and $-20^{\circ} \mathrm{C}$ at least for several minutes (Asahina, unpublished). In these egg cells, however, ice seeding into the surrounding sea water was easily followed by intracellular freezing even at a temperature, as high as $-8^{\circ} \mathrm{C}$ (Asahina, 1953). It is therefore, reasonable to assume that intracellular freezing in the egg cells at moderately low temperatures is not introduced by a spontaneous freezing of the intracellular water, but by an inoculation with extracellular ice crystals.

It has been known that the surface protoplasmic layer is a sufficient barrier to 
prevent the transmission of freezing into the supercooled cell interior (Chambers and Hale, 1932). It is also well known that water in gelatin gel is very difficult to freeze (Moran, 1926). Luyet and Rapatz (1958) revealed that ice crystals formed within gelatin gel of 50 percent in concentration, scarcely developed at temperatures above $-15^{\circ} \mathrm{C}$. On the other hand, the surface layer of a living cell has been believed to be a gel layer. In the egg cell of the sea urchin, Hemicentrotus pulcherrimus, the thickness of the surface gel layer was estimated to be $3 \mu$ in unfertilized egg and $4 \mu$ in fertilized egg immediately before the first cleavage (Hiramoto, 1957).

These observations mentioned above suggest that a decrease in cooling rate at the cell surface will be effective in preventing the ice seeding into the cell. The results presented in Table 2 may support this view. Fertilized egg cells were highly resistant to both rapid and slow freezing, while nearly all of the unfertilized egg cells could not withstand rapid freezing, although they, too, could survive slow freezing. Unfertilized egg cells treated with $1 \mathrm{M}$ urea solution, however, showed a significant increase in resistance capacity to rapid freezing. On the other hand, fertilized egg cells are well known to be more permeable to water than unfertilized egg cells (Lillie, 1916; Ishikawa, 1954). However, when previously treated with $1 \mathrm{M}$ urea solution, unfertilized egg cells, too, exhibited a high permeability to water. The high resistance to rapid freezing noted in fertilized egg cells seems to be not due to the existence of the fertilization membrane or the hyaline plasma layer both of which were formed entirely covering the cell on fertilization. This can be said because fertilized egg cells denuded by a treatment with Ca-free sea water showed nearly the same resistance as intact fertilized egg cells to rapid freezing. At the same time when they were frozen with Ca-rich sea water, both fertilized and unfertilized egg cells remarkably lost their resistant capacity to rapid freezing (Table 2). A well known effect of Ca-rich solution on sea urchin egg cells is to make the protoplasmic surface stiff (Heilbrunn, 1928).

Table 2. Resistance to a rapid freezing and the permeability to water in the egg cells of the sea urchin, Strongyrocentrotus nudus

\begin{tabular}{|c|c|c|c|}
\hline$\therefore$ & \multicolumn{2}{|c|}{$\begin{array}{l}\text { Percent survival in frozen egg cells } \\
\text { Final temp.: }-19^{\circ} \mathrm{C}\end{array}$} & \multirow{3}{*}{ Permeability* } \\
\hline & $\begin{array}{l}\text { Slow cooling } \\
1.00-1.25^{\circ} \mathrm{C} / \mathrm{min}\end{array}$ & $\begin{array}{l}\text { Rapid cooling } \\
9-10^{\circ} \mathrm{C} / \mathrm{min}\end{array}$ & \\
\hline . & $(\%)$ & $(\%)$ & \\
\hline Unfertilized egg & $90.1 \pm 4.5$ & $14.2 \pm 7.2$ & 399 \\
\hline Fertilized egg & $94.0 \pm 3.4$ & $91.2 \pm 6.6$ & 486 \\
\hline $\begin{array}{l}\text { Unfert. egg treated with } \\
\text { urea solution }\end{array}$ & $70.0 \pm 6.4$ & $56.0 \pm 5.1$ & 492 \\
\hline $\begin{array}{l}\text { Fert. egg denuded with } \\
\text { Ca-free sea water }\end{array}$ & $81.7 \pm 5.8$ & $70.8 \pm 5.8$ & 464 \\
\hline $\begin{array}{l}\text { Unfert. egg with Ca-rich } \\
\text { sea water }\end{array}$ & $79.5 \pm 7.2$ & $3.3 \pm 1.0$ & 406 \\
\hline $\begin{array}{l}\text { Fert. egg with Ca-rich } \\
\text { sea water }\end{array}$ & $90.2 \pm 3.3$ & $26.0 \pm 12.2$ & 467 \\
\hline
\end{tabular}

* Amount of water leaving eggs within 3 minutes in hypertonic (1.5-fold concentration) sea water 
The freezing process in these egg cells in sea water was observed under a special refrigerated microscope (Asahina, 1962 a). Soon after they were surrounded by ice masses, unfertilized egg cells were very liable to undergo fatal intracellular freezing provided they were rapidly cooled; but when cooled slowly, they never froze intracellularly, instead, they underwent a marked contraction resulting from extracellular freezing. Even in such a contracted state, the form of the unfertilized egg cells was not remarkably changed, being as a rule, nearly spherical (Fig. $4 \mathrm{~A}$ ). In fertilized eggs, on the other hand, no intracellular freezing was observed, even when they were rapidly cooled at a rate of about $10^{\circ} \mathrm{C}$ per minute. They always underwent extracellular freezing alone with a remarkable dehydration and contraction. Upon such a contraction, fertilized eggs, in contrast with the case of unfertilized ones, invariably changed their cell form into a very irregular or flattened shape (Fig. 4 A). The freezing process in both unfertilized eggs treated with urea solution (Fig. $4 \mathrm{~B}$ ) and fertilized eggs denuded in Ca-free sea water, was found to be almost the same as in normal fertilized eggs. Both fertilized and unfertilized egg cells in Ca-rich sea water, when rapidly cooled, easily froze intracellularly.

From all of the observations described above, the following assumption may be drawn. In extracellularly frozen cells the ice crystal on the cell surface withdraw water from the cell interior as the cooling proceeds because of the difference in chemical potential between the ice and supercooled water within the cells. The water withdrawn in this way successively crystallizes at the interface between the cell and surrounding
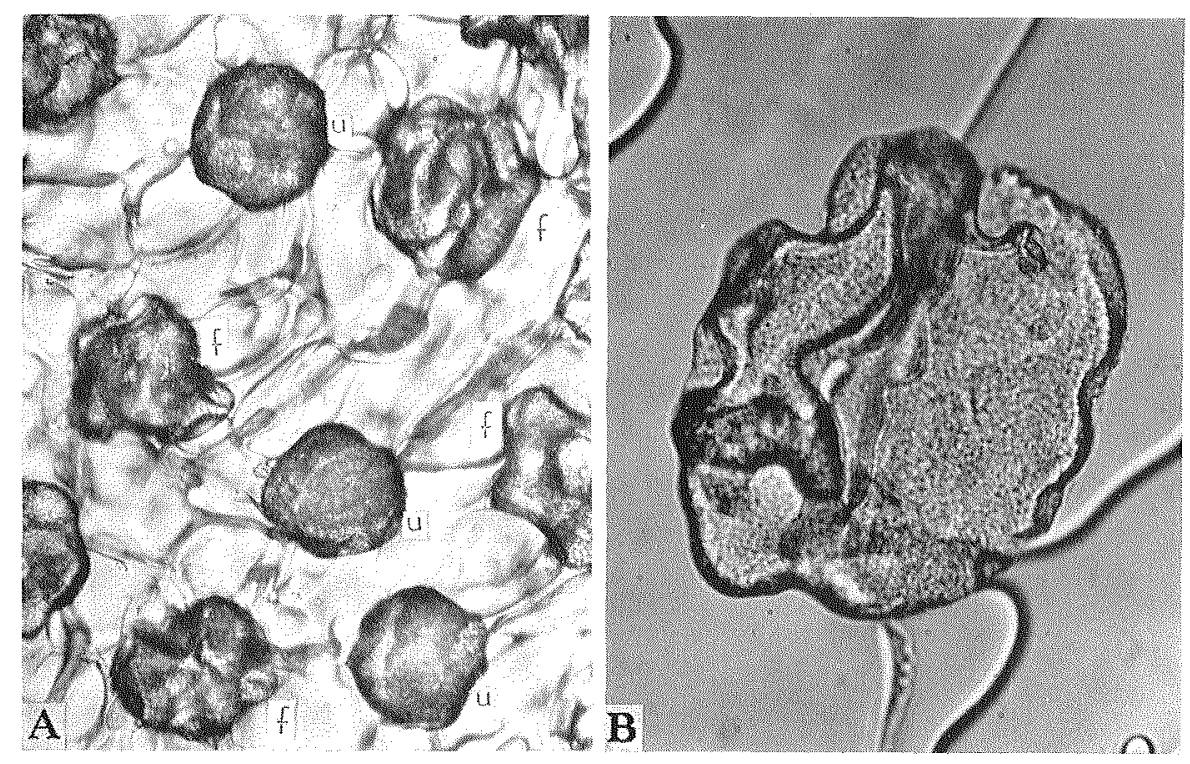

Fig. 4. Extracellular freezing of egg cells of St. nudus (from Asahina, 1962 a)

A: Both fertilized $(f)$ and unfertilized (u) egg cells at $-13^{\circ} \mathrm{C} . \quad \times 150$

B : An unfertilized egg cell at $-14^{\circ} \mathrm{C}$ previously treated with $1 \mathrm{M}$ urea solution. $\times 300$ 
ice until most of the easily freezable water at a given freezing temperature is lost from the cell. In these processes, if the cell surface is promptly cooled far below the freezing point of intracellular water at the moment, the water molecules within the protoplasmic cortical structure of the cell can be caused to arrange themselves as an ice crystal by a seeding with outside ice (Asahina, 1961). In other words, ice can grow from the outside through the fine cytoplasmic pores in the cortical gel layer into the endoplasm of the cell.

Mazur assumed that the radius of pores in a cell membrane might well be a limiting factor for the penetration of ice into the cell (Mazur, 1960). It seems however uncertain, as Mazur himself suggested later (1965), as to whether the ability of surface protoplasmic layer to block ice penetration above certain temperatures has something to do with the size of capillary pores on cell surface or not, since such an ability is readily lowered by a rapid cooling even at a high subzero temperature. For example, in a freezing cell suspension at a cooling rate of about $10^{\circ} \mathrm{C}$ per minute, intracellular freezing was most frequently observed to occur under the microscope at temperatures just below $-10^{\circ} \mathrm{C}$ in unfertilized egg cells of St. nudus. However if they were under a supercooled condition at a constant temperature of about $-8^{\circ} \mathrm{C}$ with a very small amount of sea water, an ice seeding onto the surrounding sea water film could easily cause intracellular freezing in these cells.

In any event, as long as the degree of supercooling of cell surface is kept small, the water within the surface protoplasmic gel leyer of the cell cannot crystallize and only the outside ice crystals grow. It follows, therefore, that the most effective factors . in a fertilized egg cell to prevent an intracellular freezing may certainly be a high permeability to water and a remarkable ability in the surface protoplasmic layer to deform. These two factors, by increasing the velocity of dehydration from the freezing cell can reduce the cooling rate at the cell surface where ice formation and therefore the liberation of latent heat successively occurs.

\section{Extracellular Freezing}

Nature of freezing injury. Extracellular freezing has generally been believed to be more dangerous than cooling alone to various organisms. The egg cells of the sea urchin, however, are rather resistant to extracellular freezing, although the capacity of such freezing resistance varies according to the species of the animal. For example, dangerous freezing temperatures at which fatal coagulation of the protoplasm takes place in unfertilized egg cells within a few hours are observed to be about -25 and $-15^{\circ} \mathrm{C}$ in St. nudus and Hemicentrotus pulcherrimus respectively.

In extracellularly freezing egg cells, injury usually increases as the period of time is lengthened. At a constant temperature of $-10^{\circ} \mathrm{C}$, the rate of survival decreases rather rapidly within a full day of extracellular freezing in both fertilized and unfertilized egg cells, while the freezing injury at $-20^{\circ} \mathrm{C}$ occurs more slowly in fertilized egg cells than in unfertilized ones (Table 3). One of the well known causes of injury in extracellularly freezing cells may be the so-called salt injury. Indeed, a treatment with a high concentration of artificial sea water is remarkably injurious to the egg cells at subzero temperatures as well as at ordinary temperatures. An examination of the egg 
cells suspended in artificial sea water of various high salt concentrations revealed that the injury to the egg cells by these concentrated solutions occurred much more rapidly than freezing injury at the same temperature as the freezing point of each solution (Asahina, unpublished). Since this kind of freezing injury requires rather a long time to cause appreciable damage to the egg cells, even susceptible cells to freezing can safely be cooled down to a certain low temperature, provided the rate of cooling is relatively high and the period of freezing is short.

Table 3. Percentage survival after extracellular freezing and thawing in the egg cells of Strongyrocentrotus nudus

\begin{tabular}{lccccc}
\hline & & $\begin{array}{c}\text { Unfertilized egg } \\
\text { Intact cells Developed cells** }\end{array}$ & \multicolumn{2}{c}{$\begin{array}{c}\text { Fertilized egg* } \\
\text { Intact cells }\end{array}$} \\
\cline { 1 - 1 } & $1 \mathrm{hr}$ & 98 & 95 & 98 & 98 \\
Freezing at & $6 \mathrm{hrs}$ & 95 & 65 & 83 & 80 \\
- $10^{\circ} \mathrm{C}$ for & $24 \mathrm{hrs}$ & 82 & 0 & 62 & 0 \\
& $48 \mathrm{hrs}$ & 40 & 0 & 20 & 0 \\
\hline & $1 \mathrm{hr}$ & 85 & 80 & 90 & 90 \\
& $6 \mathrm{hrs}$ & 35 & 0 & 98 & 80 \\
Freezing at & $24 \mathrm{hrs}$ & 6 & 0 & 90 & 7 \\
$-20^{\circ} \mathrm{C}$ for & $48 \mathrm{hrs}$ & 0 & 0 & 63 & 1 \\
& $72 \mathrm{hrs}$ & 0 & 0 & 22 & 0 \\
\hline
\end{tabular}

* Cells were frozen after 5 minutes from the time of insemination

** Percentage of the cells capable of cell division in the total number of frozen-thawed cells with the same treatment

A visible process of injury most frequently observed in extracellularly frozen egg cells is as follows. During a few hours of extracellular freezing at $-20^{\circ} \mathrm{C}$, a few of unfertilized egg cells of St. nudus became remarkably dark, but the other cells retained their original transparent color pattern in their protoplasm, although they were contracting remarkably (Fig. 5). With a prolonged freezing period, the number of darkened cells increased, but the rate of the increase of darkened cell became progressively small. Some of these extracellularly freezing cells also became dark in the process of slow rewarming. In such a case darkening in a cell was frequently observed to begin slowly after the cell was warmed to about $-10^{\circ} \mathrm{C}$; the darkening became gradually remarkable in the cell as the thawing proceeded. After the frozen cells had been warmed to about $-5^{\circ} \mathrm{C}$, no cells were newly found to become dark. Since these dark cells remained unchenged even after the frozen cell suspension had been completely thawed, the darkening of the protoplasm by no means suggests any intracellular ice formation in these cells, but it shows a typical coagulation of destroyed protoplasm, i.e. dark cytolysis (Heilbrunn, 1928) (Fig. 5).

The fact that the darkening in extracellularly freezing cells takes place when they have been rewarmed to about $-10^{\circ} \mathrm{C}$ may provide evidence in favor of the sulfhydryl hypothesis for freezing injury presented by Levitt (1961), because only at temperatures above $-10^{\circ} \mathrm{C}$ the fraction of liquid remarkably increases in the frozen sea water mass. 

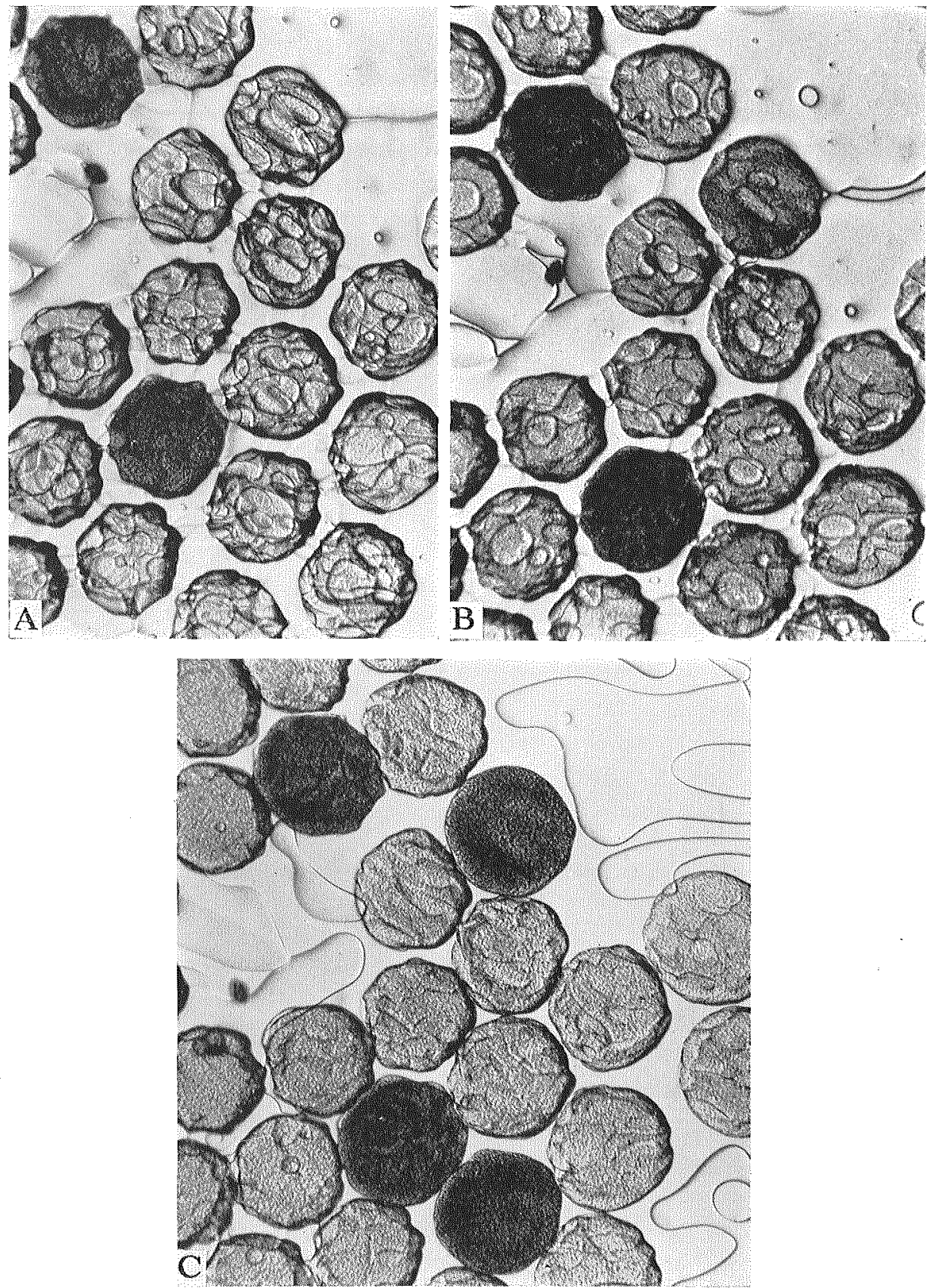

Fig. 5. Process of darkening, a fatal coagulation of protoplasm, during rewarming from extracellular freezing in unfertilized egg cells of St. nudus. $\times 130$

A: Extracellularly frozen cells, rewarmed from -20 to $-10^{\circ} \mathrm{C}$

B: Same as A, slowly rewarmed to $-6^{\circ} \mathrm{C}$

$\mathrm{C}$ : Same as $\mathrm{B}$, slowly rewarmed to $-2^{\circ} \mathrm{C}$ 
Levitt explains the injury in frozen-thawed cells as a result of intermolecular formation of disulfide bonds during extracellular freezing which produces new stresses in protoplasm at the time of swelling of contracted cells.

Fertilized cells killed by extracellular freezing invariably show a characteristic pattern of swollen cytoplasm which is clearly different in appearance from the dark cytolysis described for unfertilized egg cells (Fig. 6).

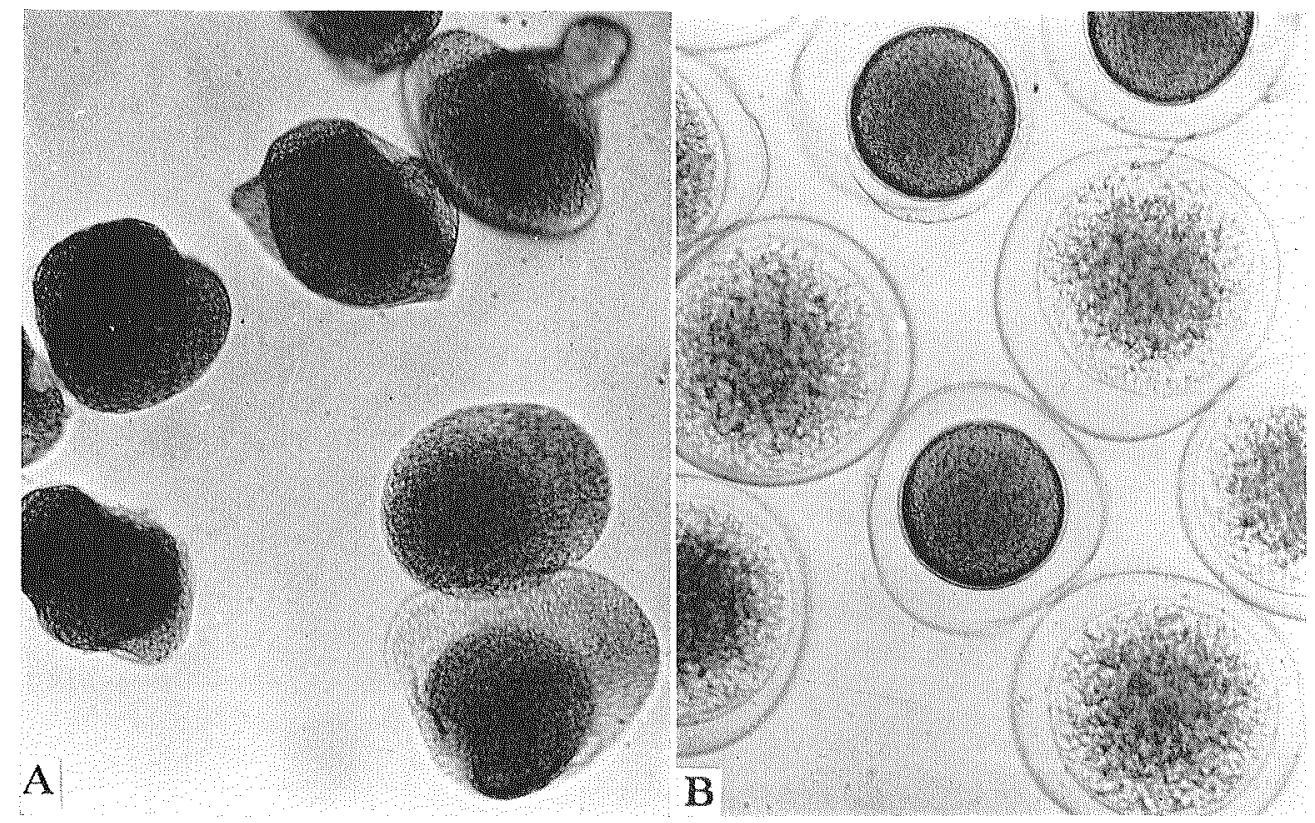

Fig. 6. Egg cells of Hemicentrotus purcherrimus, thawed from extracellular freezing at $-20^{\circ} \mathrm{C}$ for 4 hrs. $\times 170$

A : Unfertilized cells killed by freezing

B: Fertilized cells, showing 6 killed and 3 survived

In addition to the process of injury mentioned above the other mode of freezing injury, which was not fatal immediately after thawing, was observed in unfertilized egg cells. Most of cells thawed after a few hours of extracellular freezing at $-20^{\circ} \mathrm{C}$ remained as apparently intact cells. They were capable of completing the fertilization membrane following insemination; mitotic figures were observed in these cells within about 1 hour at $15^{\circ} \mathrm{C}$; cleavage even took place in some cells, but all the cells failed to develop further to blastulae. They were all destroyed with remarkable blistering on the cell surface within 1 day after thawing.

The effect of low temperature itself may also reasonably be a cause of injury in extracellularly frozen egg cells, since supercooled egg cells are remarkably damaged within several hours without freezing (Table 1). It is of interest to note that fertilized egg cells can survive freezing for a longer period of time at $-20^{\circ} \mathrm{C}$ than at $-10^{\circ} \mathrm{C}$, while unfertilized egg cells are damaged more readily at $-20^{\circ} \mathrm{C}$ than at $-10^{\circ} \mathrm{C}$ (Table 3 ). This suggests that some hindrances in the metabolic process in egg cells may certainly be involved in the cause of injury in extracellularly frozen cells, since the rate of 
metabolism in fertilized egg cells has been well known to be remarkably higher than in unfertilized ones.

Increase in resistance capacity to extracellular freezing in egg cells at the time of fertilization. As is clearly shown in Table 3, cellular resistance to extracellular freezing is remarkably different between fertilized and unfertilized egg cells. At temperatures below $-20^{\circ} \mathrm{C}$, the freezing resistance in fertilized egg cells is much higher than that in unfertilized ones. It was demonstrated in a previous paper that such a high freezing resistance was instantly produced at the time of fertilization, reached a maximum within about 5 minutes after insemination, and then gradually decreased before the mitotic apparatus was formed in the cell (Fig. 7) (Asahina and Tanno, 1963). It is of interest to note that even after only one minute from insemination the freezing resistance in the egg cell remarkably increases, because within this short period the cortical change is definitely known to occur. As mentioned before, the ability of the egg cell to prevent intracellular freezing also increases after the cortical change.

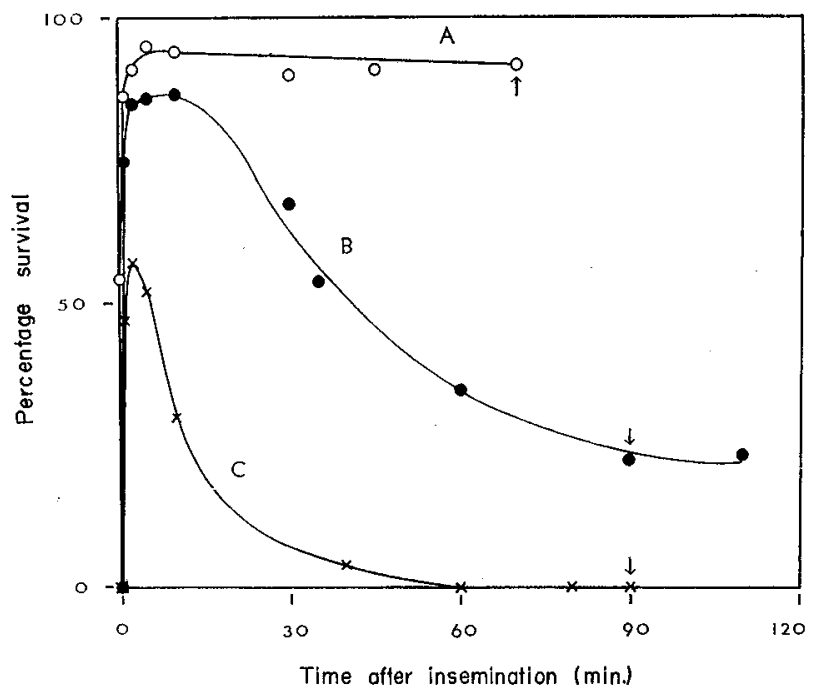

Fig. 7. Changes in freezing resistance in egg cells of St. nudus during the first cleavage. Arrows show the time of cleavage. (From Asahina and Tanno, 1963)

$\mathrm{A}(\mathrm{O})$, eggs were inseminated at $20^{\circ} \mathrm{C}$ and frozen at $-20^{\circ} \mathrm{C}$ for $4 \mathrm{hrs} ; \mathrm{B}(\bullet)$, eggs were inseminated at $16^{\circ} \mathrm{C}$ and frozen at $-22^{\circ} \mathrm{C}$ for $19 \mathrm{hrs} ; \mathrm{C}(\times)$, eggs were inseminated at $16^{\circ} \mathrm{C}$ and frozen at $-25^{\circ} \mathrm{C}$ for $18 \mathrm{hrs}$

The nature of increasing resistance to freezing in fertilized egg cells is very characteristic in its instant occurrence within a few minutes. A well known process of frosthardening in natural organisms has been an increase of some protective substances, such as polyhydric alcohol or sugar (Salt, 1961; Sakai, 1962). In the fertilized egg cells of the sea urchin, however, no appreciable increase in the amount of such small molecule substances was detected. It seems, therefore, that the process of frost-hardening in fertilized egg cells may involve structural changes in the protoplasmic protein. A 
remarkable change in the distribution of protein-bound $\mathrm{SH}$ groups in the sea urchin egg cell has been cytochemically found by Kawamura and Dan (1958) during the first cleavage; the stainability in egg cytoplasm promptly increases upon fertilization. The same staining method of a mercaptid-forming azodye as used by them was applied to the egg cells of St. nudus. As anticipated, the color intensity in cytoplasm was highest within about 10 minutes after insemination and then apparently decreased as the development proceeded (Asahina and Tanno, 1963). However, quantitative studies on SH groups in sea urchin egg cells have revealed that immediately after fertilization the fluctuation in protein SH was very small (Kawamura, 1960) and that SH in total protein precipitated by $\mathrm{HCl}$-acetone remained constant even up to the 2-cell stage (Sakai, 1960). There is, however, no reason to believe that the net increase in SH concentration in total egg protein is necessary to increase cellular freezing resistance. Some structural changes of protoplasmic protein in some component of cytoplasm may be a possible factor responsible for the enhancement of the resistance to freezing in the egg cell.

Freezing injury in relatively rapidly cooled cells. As stated before, the freezing injury assumably brought about by a high concentration of salt solution requires a rather long time to produce an appreciable damage to extracellularly freezing cells. For example, extracellular freezing on unfertilized egg cells of Hemicentrotus purcherrimus became fatal within one hour at $-15^{\circ} \mathrm{C}$, but if cooled somewhat rapidly, they can survive freezing even at $-25^{\circ} \mathrm{C}$ at least for one minute (Asahina, $1962 \mathrm{~b}$ ). Other mechanism of freezing injury may, therefore, be involved in the killing of extracellularly freezing cells which are being rapidly cooled. To examine the behavior of the cell at the time of rapid freezing, the egg cells of $H$. purcherrimus was used as material, since they, both fertilized and unfertilized, were proved to tolerate a rapid cooling rate of at least $20^{\circ} \mathrm{C}$ per minute without any formation of intracellular ice, perhaps because of their small size and the relatively high permeability to water. The data presented in Table 4 strongly suggests that the cause of injury in rapidly cooled egg cells in salt solutions may possibly be a drastic dehydration from the well hydrated protoplasmic surface of the freezing cells (Asahina, $1962 \mathrm{~b}$ ). When the egg cells were cooled to a temperature just below the eutectic point of the surrounding medium, except in the case of cells in sodium or calcium salt solutions, they were instantly destroyed at which time a prompt formation of a eutectic mixture was generally observed surrounding the egg cells under the microscope. In the solutions of sodium salts, on the other hand, the formation of eutectic mixture within a short period was found to be rather difficult at the eutectic temperature, but it did easily at a temperature about $10^{\circ} \mathrm{C}$ lower than the eutectic point. This is the reason why freezing cells in these solutions were killed at temperatures below eutectic points.

On the other hand if the egg cells were cooled to a temperature only a few degrees above the eutectic point and maintained at that temperature for 1 minute and then thawed, almost all of the cells escaped fatal injury (Table 4). This suggests that even an almost saturated salt solution is not so injurious to the freezing egg cells as to cause a fatal damage within a few minutes at least at temperatures above its eutectic point. Microscopic observation of the rapidly frozen egg cells with some single salt solutions revealed that the visible process of cellular injury is either rapid flashing of the whole 
Table 4. Percentage of sea urchin egg cells in various single salt solutions (isotonic to sea water) surviving short freezing periods*

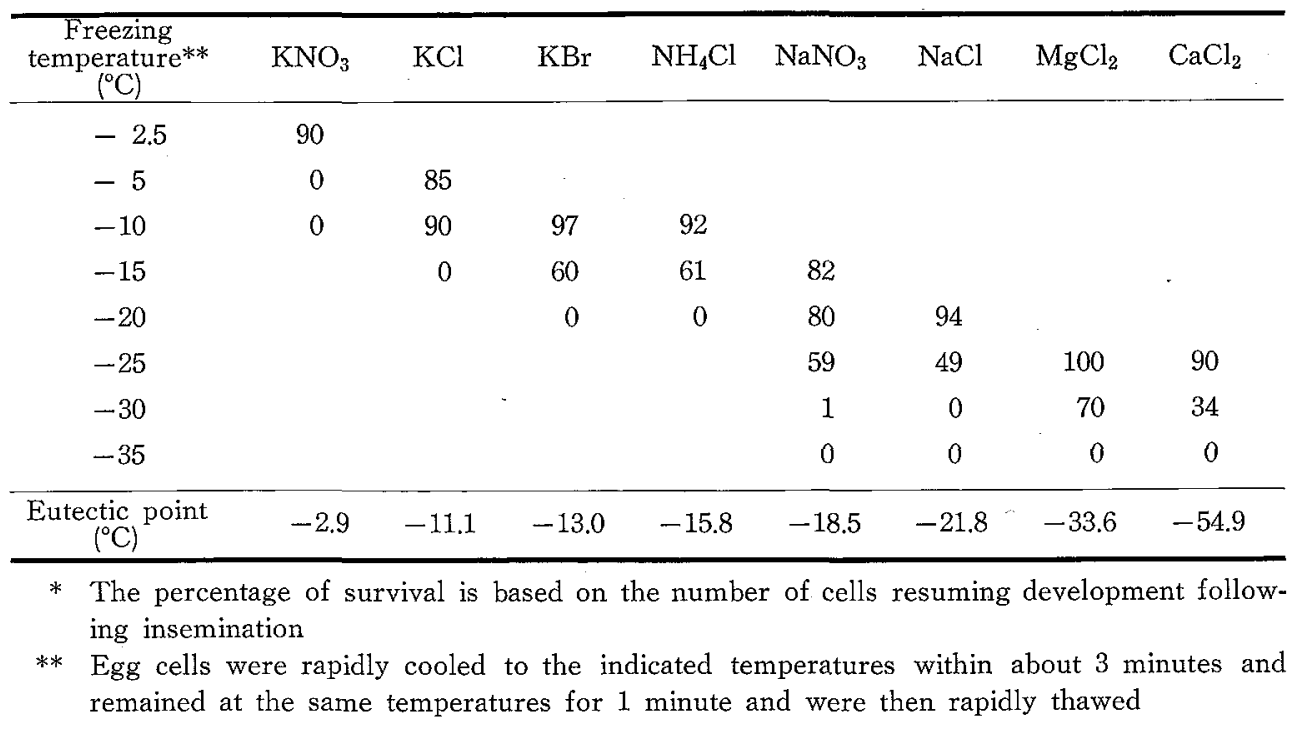

cell in the potassium salt solutions or slow darkening of protoplasm at the time of rewarming in other salt solutions (Asahina, $1962 \mathrm{~b}$ ).

From these observations it is reasonable to assume that freezing injury in the rapidly cooled cells in salt solutions may possibly be a destruction of protoplasmic structure of cell surface, perhaps by a very rapid change in the interaction between protoplasmic surface and surrounding water, since a complete removal of water from the contacting medium suddenly occurs at the time of the formation of eutectic mixture. The occurrence of flashing in the egg cells frozen in potassium salt solutions may be explained as follows. When the freezing egg cell suspension has been cooled to the eutectic point, cryohydrate begins to form in the frozen mass and comes in contact with a part of the surface of a cell where protoplasmic structure is instantly destroyed. This may result in a sudden flashing of the whole cell, since the cells suspended in potassium salt solutions have still a lot of easily freezable water within them even at the eutectic temperature of the medium, and intracellular seeding can, therefore, be easily achieved from the destroyed part of cell surface with outside ice crystals. In fact, when one of the salt crystals, which crystallized out from the frozen salt solution at the eutectic point, grew to the surface of an egg cell, a pronounced darkening due to the formation of very fine ice crystals rapidly spread over the whole cell from the spot touched by the salt crystal (Fig. 8). On the other hand, solutions of sodium or magnesium salts have their eutectic points at temperatures around $-20^{\circ} \mathrm{C}$ or below. In addition, as described before, a metastable state without cryohydrate formation in these frozen solution is easily attainable even at temperatures below their eutectic points. Therefore, the freezing egg cells in these solutions are severely dehydrated by extracellular freezing, but never undergo flashing, since they have hardly any freezable water inside the cell when they have been cooled down to the danger-point temperature. 

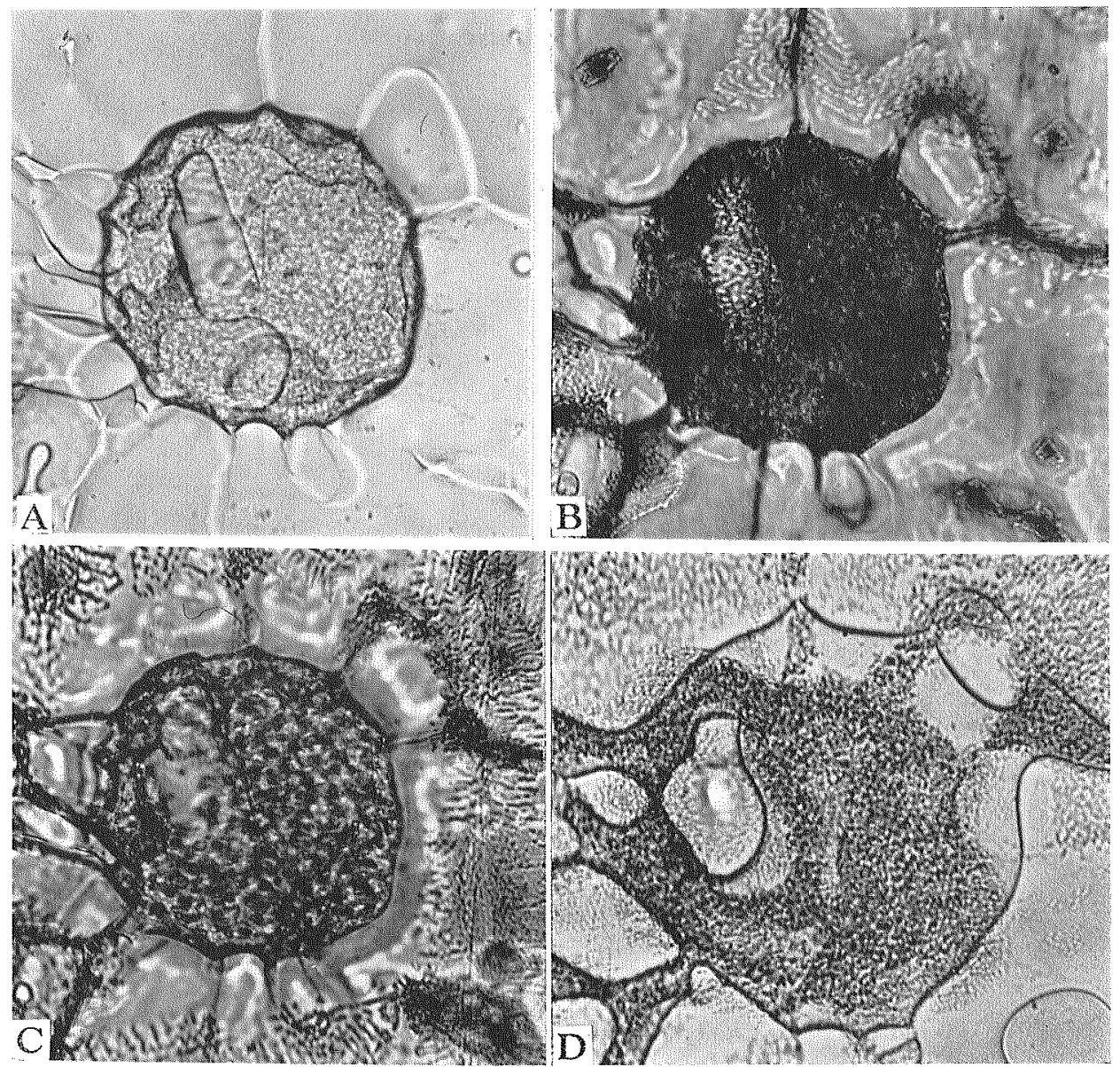

Fig. 8. Process of freezing injury in the egg cell of St. intermedius frozen in $0.5 \mathrm{M} \mathrm{KCl}$ solution. $\times 380$

A : Extracellular freezing at $-10^{\circ} \mathrm{C}$

$\mathrm{B}$ : Same as $\mathrm{A}$, at $-13^{\circ} \mathrm{C}$, immediately after flashing at the time of the formation of cryohydrate in the medium

C: Same as B, 1 minute later at $-13^{\circ} \mathrm{C}$

$\mathrm{D}$ : Same as $\mathrm{C}, 12$ minutes later, thawing at $-2^{\circ} \mathrm{C}$. Cell is completely destroyed

The freezing injury in the egg cells suspended in calcium chloride solution may be somewhat different in nature from that in other salt solutions, since the eutectic point is far lower than their danger-point temperature. A well known effect of calcium salt solution to make the protoplasmic surface stiff and brittle (Heilbrunn, 1928), may perhaps be one of the causes of injury in these cells at the time of both rapid freezing and thawing.

Injury caused by a rapid thawing. It has long been known that a rapid thawing from extracellular freezing is very injurious to some plant cells (Iljin, 1934; Levitt, 1956), while the same procedure is usually better than slow thawing to obtain good survival in various kinds of animal cells (Smith, 1961). Experimental results presented in Table 5 
however, demonstrated that egg cells of the sea urchin also suffer serious injury by a rapid thawing. More than two thirds of the total number of egg cells were killed by a rapid thawing from an extracellular freezing at $-20^{\circ} \mathrm{C}$, while practically all the egg cells survived slow thawing. At a temperature range between -20 and $-10^{\circ} \mathrm{C}$, rapid thawing was also harmful although the percentage of killed cells is rather small. When the egg cells frozen at $-20^{\circ} \mathrm{C}$ were rewarmed slowly to $-10^{\circ} \mathrm{C}$ and then thawed rapidly, they suffered severe injury comparable to that in the egg cells rapidly thawed directly from $-20^{\circ} \mathrm{C}$. However after the egg cells had been slowly warmed to $-5^{\circ} \mathrm{C}$, rapid thawing was rather harmless to the frozen egg cells (Table 5). It is of interest

Table 5. Effect of rewarming procedure on percentage survival of extracellularly frozen egg cells*

\begin{tabular}{|c|c|c|}
\hline Rewarming procedure & $\begin{array}{l}\text { Warming rate between } \\
-10 \text { and }-5^{\circ} \mathrm{C}\end{array}$ & $\begin{array}{l}\text { Survival*** } \\
(\%)\end{array}$ \\
\hline Rapidly thawed in water at $25^{\circ} \mathrm{C}$ & about $40^{\circ} \mathrm{C} / \mathrm{min}$ & $31.8 \pm 7.5$ \\
\hline $\begin{array}{l}\text { Slowly rewarmed to }-10^{\circ} \mathrm{C} \text { and then } \\
\text { rapidly thawed in water at } 20^{\circ} \mathrm{C}\end{array}$ & about $35^{\circ} \mathrm{C} / \mathrm{min}$ & $37.2 \pm 8.8$ \\
\hline $\begin{array}{l}\text { Rapidly transferred into brine at }-10^{\circ} \mathrm{C} \\
\text { and then thawed slowly in air at } 0^{\circ} \mathrm{C}\end{array}$ & about $\quad 3^{\circ} \mathrm{C} / \mathrm{min}$ & $73.3 \pm 9.8$ \\
\hline $\begin{array}{l}\text { Slowly rewarmed to }-5^{\circ} \mathrm{C} \text { in air and } \\
\text { then rapidly thawed in water at } 20^{\circ} \mathrm{C}\end{array}$ & about $2^{\circ} \mathrm{C} / \mathrm{min}$ & $76.1 \pm 8.5$ \\
\hline Slowly thawed in air at $0^{\circ} \mathrm{C}$ & about $2^{\circ} \mathrm{C} / \mathrm{min}$ & $94.1 \pm 6.0$ \\
\hline
\end{tabular}

* Unfertilized egg cells of the sea urchin, Strongyrocentrotus nudus were employed as material. Test tubes, containing a small amount $(0.25 \mathrm{ml})$ of frozen mass of cell suspension in sea water, were rewarmed from $-20^{\circ} \mathrm{C}$

** Mean values of 5 experiments

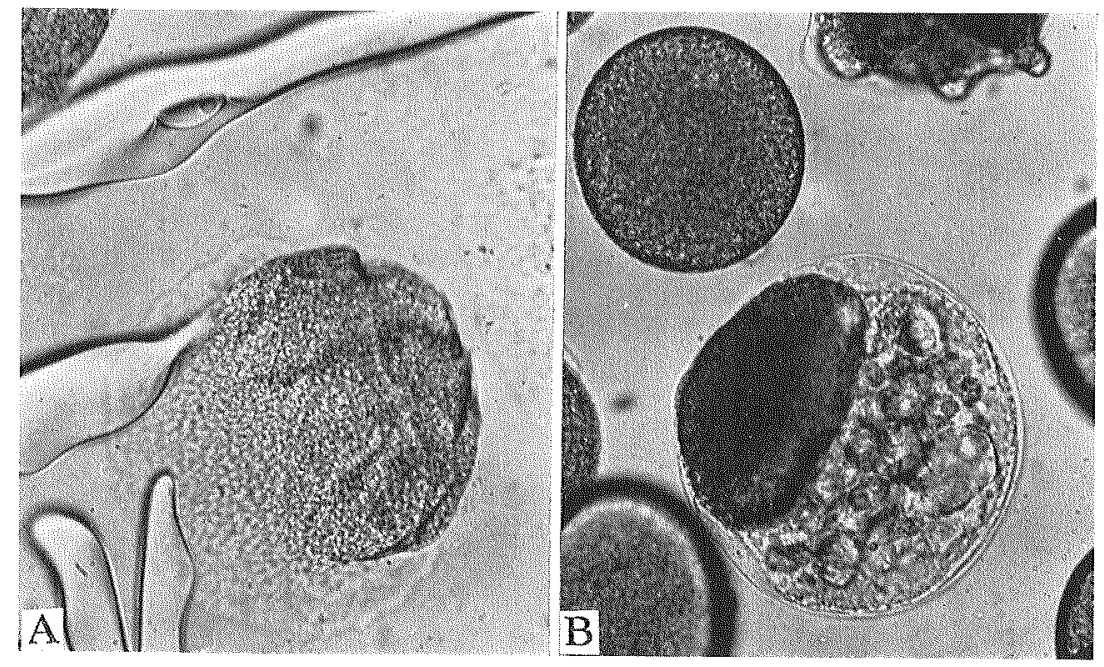

Fig. 9. Injury by rapid thawing from extracellular freezing at $-20^{\circ} \mathrm{C}$ in the egg cells of St. nudus. $\times 220$

A : Burst

B: Cytolysis with remarkable vacuolization. An intact cell seen in upper left corner survived rapid thawing 
to riote that between -5 and $-10^{\circ} \mathrm{C}$ rapid thawing becomes remarkably harmful for the egg cells, since only at temperatures above $-10^{\circ} \mathrm{C}$ the amount of melted ice becomes remarkable in a frozen mixture of sea water. A microscopic observation revealed that the unfertilized egg cells of St. nudus were very likely to undergo fatal vacuolization or sometimes even an apparent burst of the cell itself during rapid thawing (Fig. 9). These results seem to suggest that the cause of injury by rapid thawing from extracellular freezing may perhaps be a mechanical damage in the surface protoplasmic layer brought about by a rapid expansion or swelling of the cell at the time of rapid thawing. The fact that at temperatures above $-5^{\circ} \mathrm{C}$, the thawing injury in rapidly warmed cells is no more severe may suggest that after the cell has swollen to some extent the protoplasmic surface structure in most of the cells can expand back to normal form without any damage even if the expansion is fairly rapid.

\section{References}

ASAHINA, É. 1953 Analysis of the freezing process of living organisms. X. Freezing process of egg cell of sea urchin. Low Temp. Sci., 10, 81-92 (In Japanese with English summary).

ASAHINA, E. 1961 Intracellular freezing and frost-resistance in egg cells of the sea urchin. Nature, 191, 1263-1265.

ASAHINA, É. 1962 a A mechanism to prevent the seeding of intracellular ice from outside in freezing living cells. Low Temp. Sci., B 20, 45-56 (In Japanese with English summary).

AsaHINA, É. $1962 \mathrm{~b}$ Frost injury in living cells. Nature, 196, 445-446.

ASAHINA, É, 1965 Freezing process and injury in isolated animal cells. Fed. Proc., 24, Suppl. 15, S-183-187.

ASAHINA, É. and TANNO, K. 1963 A remarkably rapid increase of frost-resistance in fertilized egg cells of the sea urchin. Exptl. Cell Res., 31, 223-225.

Chambers, R. and Hale, H. P. 1932 The formation of ice in protoplasm. Proc. Roy. Soc, B 110, 336-352.

GeHENio, P. M. and LUYYeT, B. J. 1939 A study of the mechanism of death by cold in the plasmodium of the myxomycetes. Biodynamica, 2, No. 55, 1-22.

HeIlbRUnN, L. V. 1928 The Colloid Chemistry of Protoplasm. Protoplasma Monographien, 1, Berlin, $356 \mathrm{pp}$.

Hiramoto, Y. 1957 The thickness of the cortex and the refractive index of the protoplasm in sea urchin eggs. Embryologia, 3, 361-374.

ILJIN, W. S. 1934 The point of death of plants at low temperatures. Bull. Assoc. russe Rech. Sci, Prague, 1, No. 4, 1-26.

ISHIKAWA, M. 1954 Relation between the breakdown of the cortical granules and permeability to water in the sea urchin egg. Embryologia, 2, 57-62.

KAWAMURA, N. 1960 Cytochemical and quantitative study of protein-bound sulfhydryl and disulfide groups in eggs of Arbacia during the first cleavage. Exptl. Cell Res., 20, 127-138.

KAWAMURA, N. and DAN, K. 1958 A cytochemical study of the sulfhydryl groups of sea urchin eggs during the first cleavage. J. Biophys. Biochem. Cytol., 4, 615-620.

Levit, J. 1956 The Hardiness of Plant. Academic Press, New York, 278 pp.

LEVITT, J. 1962 Sulfhydryl-disulfide hypothesis of frost injury and resistance in plants. J. Theoret. Biol., 3, 355-391.

LILLIE, R. S. 1916 Increase of permeability to water following normal and artificial activation in sea-urchin eggs. Amer. J. Physiol., 40, 249-266.

LUYET, B. J. and GrBBS, M. C. 1937 On the mechanism of congelation and of death in the rapid 
freezing of epidermal plant cells. Biodynamica, 1, No. 25, 1-18.

LUYET, B. J. and RAPATZ, G. 1958 Patterns of ice formation in some aqueous solutions. Biodynamica, 8, 1-68.

MAZUR, P. 1960 Physical factors implicated in the death of microorganisms at subzero temperatures. Ann. N: Y. Acad. Sci., 85, 610-629.

MAzUR, P. 1965 The role of cell membranes in the freezing of yeast and other single cells. Ann. N. Y. Acad. Sci., 125, 658-676.

Moran, T: 1926 The freezing of gelatin gel. Proc. Roy. Soc., A 112, 30-46.

SAKAI, A. 1962 Studies on the frost-hardiness of woody plants. I. The causal relation between sugar content and frost-hardiness. Contr. Inst. Low Temp. Sci., B 11, 1-40.

SAKAI, H. 1960 Studies on sulfhydryl groups during cell division of sea urchin egg. II. Mass isolation of the egg cortex and change in its $-\mathrm{SH}$ groups during cell division. J. Biophys. Biochem. Cytol., 8, 603-607.

SAlt, R. W. 1961 Principles of insect cold-hardiness. Ann. Rev. Entomology, 6, 55-74.

SMITH, A. U. 1961 Biological Effect of Freezing and Supercooling. Edward Arnold Ltd., London, 424 pp. 